\title{
"We work by the second!" Piecework remuneration and occupational health and safety from an ethnicity- and gender-sensitive perspective
}

"On travaille à la seconde!" Rémunération à la pièce et santé et sécurité du travail dans une perspective qui tient compte de l'ethnicité et du genre

«Trabajamos al Segundo!» Remuneración por pieza y salud y seguridad en el trabajo en una perspectiva que toma en cuenta la etnicidad y el género

Stephanie Premji, Katherine Lippel and Karen Messing

\section{OpenEdition}

Journals

\section{Electronic version}

URL: http://journals.openedition.org/pistes/2193

DOI: $10.4000 /$ pistes. 2193

ISSN: 1481-9384

Publisher

Les Amis de PISTES

Printed version

Date of publication: 1 May 2008

Electronic reference

Stephanie Premji, Katherine Lippel and Karen Messing, " "We work by the second !" Piecework remuneration and occupational health and safety from an ethnicity- and gender-sensitive perspective », Perspectives interdisciplinaires sur le travail et la santé [Online], 10-1 | 2008, Online since 01 May 2008, connection on 30 April 2019. URL : http://journals.openedition.org/pistes/2193; DOI : 10.4000/ pistes.2193

This text was automatically generated on 30 April 2019.

\section{cc) (1)}

Pistes est mis à disposition selon les termes de la licence Creative Commons Attribution - Pas d'Utilisation Commerciale - Pas de Modification 4.0 International. 


\title{
"We work by the second !" Piecework remuneration and occupational health and safety from an ethnicity- and gender-sensitive perspective
}

\author{
"On travaille à la seconde!" Rémunération à la pièce et santé et sécurité du \\ travail dans une perspective qui tient compte de l'ethnicité et du genre \\ «Trabajamos al Segundo!» Remuneración por pieza y salud y seguridad en el \\ trabajo en una perspectiva que toma en cuenta la etnicidad y el género
}

Stephanie Premji, Katherine Lippel and Karen Messing

\section{Introduction}

1 According to the 1998 Québec Health and Social Survey (Institut de la Statistique du Québec 2001), 14.1\% of Québec workers are paid on the basis of piecework, commissions or bonuses at least occasionally. The Survey indicated that proportionately more men than women were paid on one of these three bases. Data have shown, however, that women are more often engaged in piecework, and less often in work involving commissions or bonuses (Geddes and Heywood 2003). There are no quantitative data on ethnic groups' involvement in piecework, but qualitative studies have pointed to a high proportion of immigrants in workplaces offering this form of remuneration. The same studies have described the socio-economic uncertainties associated with this reality (Herzog 1980; Park and Pellow 2005).

2 Several epidemiological studies have examined piecework remuneration as a risk factor for health in manufacturing. Although some studies did not find any clear link between 
piecework and health problems (Goulet and Thériault 1987; Nadeau et al. 1990; Schibye et al. 1995; Wrench and Lee 1982), others have associated this kind of remuneration with accidents and disease (Mayhew and Quinlan 1999), severe disabilities (Brisson et al. 1989; Vézina et al. 1989) or the use of medication (Vinet et al. 1989). In these studies, the underlying mechanisms are evoked in terms of factors such as the frequency of movements and time constraints. These factors have been associated with physical and psychological health problems in the workplace (Punnett et al. 2000; Silverstein et al. 1986; Teiger 1973).

3 There are not many qualitative studies describing the mechanisms that link piecework and health. From a sociological perspective, Cheng (1997) reported the experiences of people who suffered hand injuries in Hong Kong and their accounts of the causes of their injuries, including the influence of piecework on their attitudes and behaviour. Klein (1964) has also presented the comments of workers paid on a piecework basis, mentioning, for instance, the link between the pace of their work and their level of fatigue. Looking at ergonomics, Vézina and her colleagues (1992) analysed the work of sewing machine operators on a piecework basis and described heavy physical workloads and their relationship to the musculoskeletal disorders they reported. Another ergonomic study of sewing machine operators in a boot factory, done after the introduction of a modular system involving a method of piecework remuneration calculated for each module, presented an analysis of the components of the work and its organization, emphasizing in particular the impact of work organization on relational dynamics and the link between these factors and the musculoskeletal disorders observed (Vézina et al. 2003).

4 The literature in sociology has also examined the relational dynamics engendered by piecework, but touching only indirectly on links with health. The work of the sociologist Donald Roy (1952; 1953; 1954; 2006a), based on his experience as an employee in a machine shop in the United States in the 1940s, and those of his colleague Michael Burawoy (1979), employed in the same shop thirty years later, are classic examples of participant observation narratives. Miklós Haraszti (1977) has also described social and work relations created by this form of remuneration in the context of a tractor plant in Hungary. From a feminist perspective, Marianne Herzog (1980) produced rich descriptions of entire days of piecework, based on her experience working in various West German factories in the 1970s. Looking at Montreal in the 1980s, Labelle and her colleagues (1987) drew attention to the physical and psychological conditions of piecework in manufacturing, using accounts by immigrant women workers. Their narratives illustrated in particular their difficult relations with employers, supervisors and colleagues as well as problems in balancing work and family. Thus a qualitative method would seem to be ideal for relating these rich descriptions of conditions to the results of epidemiological studies by examining the multiple links between the demands and constraints of work and the effects on health.

\section{Objectives}

The main objective of our study is to describe qualitatively, in the context of a Montréal garment factory, the mechanisms through which piecework affects health, and to identify the role of ethnicity and gender in these dynamics. A secondary objective is to compare the realities of piecework with the way it is depicted by the various parties involved 
(employers, workers, decision-makers, physicians), as reported in appeal decisions on workers' compensation claims.

\section{Methodology}

6 This study is based on data from two sources: individual interviews, and appeal decisions on compensation claims. These are entirely separate samples, meaning that in analysing the decisions on claims, no attempt was made to include claims that might have been made by subjects interviewed, and vice versa.

\subsection{Interviews}

7 The interviews were conducted at a major garment factory in Montréal ("Confection inc." $\left.{ }^{1}\right)$ where the majority of jobs are paid on a piecework basis. The company's work force is typical of the industry, composed of a majority of women ( $70 \%)$ and immigrants ( $98 \%)$ from just over 40 countries of birth. ${ }^{2}$ Between 2004 and 2006, we did 25 interviews with 15 women workers and 10 men workers born in 14 different countries (22 immigrants and 3 non-immigrants), selected because they reflected the ethnic make-up of the work force and because they covered a range of ages, immigration periods, linguistic skills, family situations, job categories and work-related health status (declared employment injuries or illnesses or not, with or without compensation claims). Potential subjects were identified with the help of the union and the company's human resources department, using these criteria. The women ranged in age from 19 to 62 , and the men from 21 to 51 . The interviews were conducted in French (12), English (9) or another language with the assistance of co-workers who acted as interpreters (4). The interviews were transcribed, coded with Atlas-ti software and analysed using certain principles of qualitative analysis (Miles and Huberman 1984) and a gender-sensitive approach (Messing et al. 2003). Since the interpreters (two women and two men) were company employees, they sometimes gave their own viewpoints, and this information was incorporated into the analyses. At the end of the analysis, the conclusions were submitted for validation to a group of workers (men and women) who had not participated in the original interviews. It should be noted that we also did workplace observation at various times during the project, for a total of 25 hours. The project was carried out in collaboration with the union, affiliated with the Fédération des travailleurs et travailleuses du Québec (FTQ), and was approved by the Ethics Committee of the Université du Québec à Montréal. Table 1 presents some of the individual and occupational characteristics of the interviewees and the interpreters.

\subsection{Case law}

We examined 62 published and unpublished decisions rendered on appeal to the Commission des lésions professionnelles (C.L.P.) over a seven-year period (2000-2007) on claims made under the Act respecting industrial accidents and occupational diseases ${ }^{3}$ for compensation for an employment injury or illness. The decisions were identified by searching the C.L.P.'s data bank (in French) using the key words "à la pièce" (in the full text of the rulings) and "lésion professionnelle" (in the index) or "maladie professionnelle" (in the index). We selected the decisions mentioning piecework that dealt with the garment industry. For each decision, we read the summary of the decision 
and then searched the full text by keywords (e.g., "cadence," "production," "productivité," "pièce(s)," “efficacité," “quotas," "répétition," etc.) to identify what the various stakeholders had to say about piecework. Themes were then identified based on quotations for each group of stakeholders. The analysis deals solely with decisions rendered by the appeal board (C.L.P.), because these are the only ones that are publicly accessible.

\section{Results}

\subsection{Background and context}

9 The garment industry in Québec has been in decline since the 1990s, with almost 13,000 jobs lost between 1990 and 1999. Various factors are responsible for the trend: more open markets, the trend towards a free-market economy - particularly through deregulation and the restructuring of the industry through corporate consolidation and globalization of corporate activities (Pilon 2005). In this context, layoffs are a constant threat for employees as well as for the unions, which have only very limited leeway for bargaining. At Confection Inc., the negotiations and vote on the latest collective agreement reflected this, as $\mathrm{Carl}^{4}$ explained:

I feel it, I feel the fear!... Perhaps they say to themselves... "I want to keep my job." Because when I got the collective agreement... I was in the room, and then they said, "You can go and vote," and before, they said, "If you have questions to ask, go ahead and ask them!" So I raised my hand and went to the mike... I said, "We won't have any raise for three years." But people weren't listening anymore! Because they just wanted to sign... because they didn't want to lose their job.

The last collective agreement resulted in financial losses for workers, particularly because the annual bonus and pay for some holidays were now calculated on the base rate of pay instead of the pay for average production, which is higher. Because of this, a number of workers, including Karima, talked about the work being intensified:

Some people say "Ok after vacation I'm going to make my production more". I start to hear that because the company gives the new rules now, the agreement that they sign with the union...So the people now...they don't want to stop. They continue to work, piecework, piecework.

11 The garment industry has been deregulated in recent years. Decrees that had covered certain sub-sectors of the garment industry in Québec since 1934 were abolished in 1999-2000 (Morin and Brière 2003). The decrees defined certain working conditions in the industry with the dual objective of standardizing the working conditions of unionized and non-unionized workers and protecting employers against unfair competition. The decrees were administered by committees composed of equal numbers of employer and union representatives.

12 At the present time, minimum working conditions are governed by the Act respecting labour standards, ${ }^{5}$ which covers conditions such as rates of pay, duration of work, breaks and holidays. There are certain specific conditions for certain categories of employees, such as employees in the garment industry. For them, the regular work week is 39 hours instead of 40 , the minimum rate of pay is $\$ 8.25$ an hour instead of $\$ 8.00$, and there are differences in paid unworked statutory holidays, the number of days of annual vacation and amount of vacation pay, and days off for a death or funeral. ${ }^{6}$ The prevention of workrelated health problems is governed by the Act respecting occupational health and safety, 
which sets out the various rights and obligations of all employees and employers. For instance, Section 51 requires the employer to take the measures necessary to protect workers' health, safety and physical well-being. In addition to material conditions of work, the Act imposes obligations regarding the organization of work. ${ }^{8}$

\subsection{Piecework, gender and ethnicity}

13 At Confection Inc., the majority of people (both interviewees and interpreters) for whom we have information do piecework (16/27) (see Table 1). The employees who are paid by the hour have an hourly rate because of their job (quality control, auxiliary duties, general work) or because they have been temporarily assigned to light duties due to health problems or pregnancy. Some of the hourly-rated people have previously worked on a piecework basis and vice versa.

14 Company data ${ }^{9}$ indicate gender differences in forms of remuneration: $14 \%$ of male workers are paid on a piecework basis, compared with $53 \%$ of female workers. The difference is related to the kind of work done by men and women. For example, in both our sample and observations, we saw that the vast majority of sewing machine operators are women, while the vast majority of auxiliary workers (who move materials around and distribute them) are men. Some jobs, like presser and cutter, are divided equally between women and men (see Table 1). But there are gender differences in the kinds of work done within a given job title. For example, male cutters generally use cutting machines, while female cutters generally use scissors. This division of work sometimes seems to be the workers' choice (they ask for the jobs), and sometimes the company's (it offers the jobs to male or female workers). There doesn't seem to be an ethnic division of the work, either among workers or between workers and supervisors. In fact, the company's policy is to mix ethnic groups on the floor. According to company officials, the objective is to prevent the creation of "clans"; it is hard, however, to know whether the goal is to prevent conflicts between groups or solidarity within groups.

\subsection{The work force}

Confection Inc.'s workers have particular socio-economic realities because of factors related to gender and ethnicity. Ethnicity at this company is intertwined with the reality of immigration, since the work force is largely immigrant. Understanding these realities is important to understanding what, apart from work requirements and constraints, are the reasons for attitudes and behaviour with respect to piecework, and to grasping the real consequences of the work on people's health.

16 First, being an immigrant can entail additional financial responsibilities. Some of these are related to procedures associated with immigrant status (permanent resident, sponsorship applications, etc.) that can generate thousands of dollars in lawyers' fees. Others are family-related. For example, of the 16 immigrants for whom we have this information, 10 send money back to their homeland regularly or occasionally $(4 / 8$ women, $6 / 8$ men). Léa, who sends hundreds of dollars back home every month, explains that her decision to come to Canada was connected to the need to help her family:

That was really one of the reasons, one of the main reasons, for coming to Canada...

To help my relatives...My mother, my sister and her kid, three people... Because my

father is dead and my mother doesn't work. And my sister is divorced. 
17 A few people also mentioned financial responsibilities for their extended family in Canada. These are not just moral obligations, but sometimes legal ones as well, the result of official sponsorship. Some said that they were their family's sole support, either because their husband or wife was studying or because their wife stayed home, sometimes for cultural reasons. Women reported being the sole breadwinners because they were single parents, a reality that is not confined to immigrant women. As well, many immigrants mentioned personal sacrifice for the sake of their children:

I want to continue my studies...My wife don't want to spend all the money on school...She wants to save for deposit for future for kids. She says "We have difficulty now, we won't let our next generation have the same problems as us". So we deposit for them. Ben

18 In this context, piecework is an attractive option, because it offers the possibility of earning more by working harder. But there is a trade-off in terms of health:

The purpose is to be efficient, not to protect your health... As a husband you have to overcome something, you cannot think too much about your health, you have responsibility. We have no choice, if you don't work hard, if you don't push yourself, you earn only $\$ 7.45$ per hour. ${ }^{10}$ It's not enough, you should earn more. Ben

19 Piecework is contradictory, though, because although it can give workers some control over their pay or, as Haraszti put it, "a semblance of independence" (1977, p. 56), it may at the same time entail tremendous insecurity, because the results of this work are uncertain (see also Klein 1964). At Confection Inc., Isabelle explained:

I was extremely stressed out: “Am I going to make my production target?"... Because I'm raising my children all by myself. So I said to myself, "I mustn't let my pay drop too much." Because when you're raising two children and you're on your own, you don't have support payments, you can't afford to say one week, "Well O.K., it's doesn't really matter if I don't make my target."

20 Immigrants' additional financial responsibilities also push some people to work overtime whenever they can, ${ }^{11}$ before or after regular hours of work, or during part of their lunch hour, or on Saturdays:

Before, I work until nine o'clock.... That time I saw only immigrant people.... Maybe because our problem and their problem [that of non-immigrants] is not the same. Shakeel

21 This financial burden also means that for a number of workers, their job at Confection Inc. is not the only one. Of the 18 people for whom we have this information, 6 said that they had at least one other job (3/11 women, $3 / 7$ men). For example, Marie-Ève explained that she sells baked goods to her co-workers at Confection Inc. during breaks and lunch to help out her brother, a pastry cook:

I walk everywhere in the company (laughs). I'm always walking because of my activity there. When I'm not working, I get orders from the others to bring in Fridays (laughs). And I'm always walking.

In addition to overtime and extra jobs, some people said that they were taking courses to learn one of Canada's two official languages, to upgrade their qualifications or to learn a new trade. In fact, of the 18 people for whom we have this information, six said that they were taking one or more courses (2/11 women, $4 / 7$ men).

Finish work four o'clock. I stay two hours in the cafeteria...I study something. Two days I learn French [classes offered in the cafeteria after work]. Four to six. After six o'clock going to study [in a technical school]. After go back to home ten thirty...When I go back home I am very, very tired. Like a dead body. Ahmad 
It is important to know that many workers at Confection Inc. have experienced professional deskilling. Eight of the 21 people for whom we have the information mentioned having a university level of education (2/10 women, 6/11 men). Workers' fields of training were varied, ranging from computer sciences to medicine, engineering or haute couture. So upgrading and training courses are very important.

The women are primarily responsible for family duties, which might explain their lower level of participation in additional activities (extra jobs, courses). Although some women have help from their extended family on a daily basis for housework and childcare, most of them don't. Of the 17 women for whom we have this information, only 4 mentioned receiving this kind of assistance.

You get home and there's more piecework for you there. I always say to my boss,

"I'm on piecework until 8:30 at night," because you have to make the meal, feed your child, give him a bath, talk to him a little. Léa

These realities affect workers' health in different ways. The intensity of work and the duration of exposure to hazards in the same or different jobs affect the degree of exposure as well as recovery. Courses and family responsibilities also affect recovery.

\subsection{Production requirements}

At Confection Inc., shifts are 8 hours long (7 hours on Fridays), including two paid breaks of 15 minutes each that are granted and imposed by the employer. Workers have one unpaid hour for lunch. For each task paid on a piecework basis, company engineers set a production quota based on distances and time-and-motion estimates. Studies indicate that the objective of engineers is basically to maximize production, without taking workers' physiological and psychological needs into consideration (London and Bhattacharya 1985; Wells et al. 2007). Quotas are established on the basis of a 7.5-hour day, to take into account the two 15-minute breaks. This number is then divided by 8 hours to arrive at the number of pieces that have to be produced an hour (e.g., 1,600 pieces per 7.5-hour day; 1,600 pieces / 8 hours $=200$ pieces an hour). Production is calculated according to the number of bundles of garments produced. Bundles are batches of similar pieces to be sewn, with a corresponding ticket. Workers pass the tickets attached to the bundles in a machine located at their work station. This computerized system allows workers and the employer to see what their production is at any time. Workers must complete their shift even if they fill their quotas before the end of the day.

When workers produce $100 \%$ of their quota, they are paid at the rate corresponding to their job classification. The rate is reduced if their production is less than $100 \%$, and raised if they exceed $100 \%$. The rate can never be lower than the base rate of pay, however, which is determined by seniority. The absolute minimum corresponds to the general minimum wage. A minimum production level of $85 \%$ is required to keep one's job, and there is no maximum production..$^{12}$ The principle of quota-based payments is illustrated in Figure I. Average individual production, calculated over various time scales, determines the rate of pay for holidays, annual bonuses, vacations, overtime and hourlypaid work assigned to workers when production is impossible - because of a breakdown, for example, or a lack of material. 
Figure 1. Quota payments at Confection Inc. for a job class paid $\$ 10 /$ hour for $100 \%$ production, for a worker whose base rate is the minimum wage $(\$ 8 /$ hour $)$

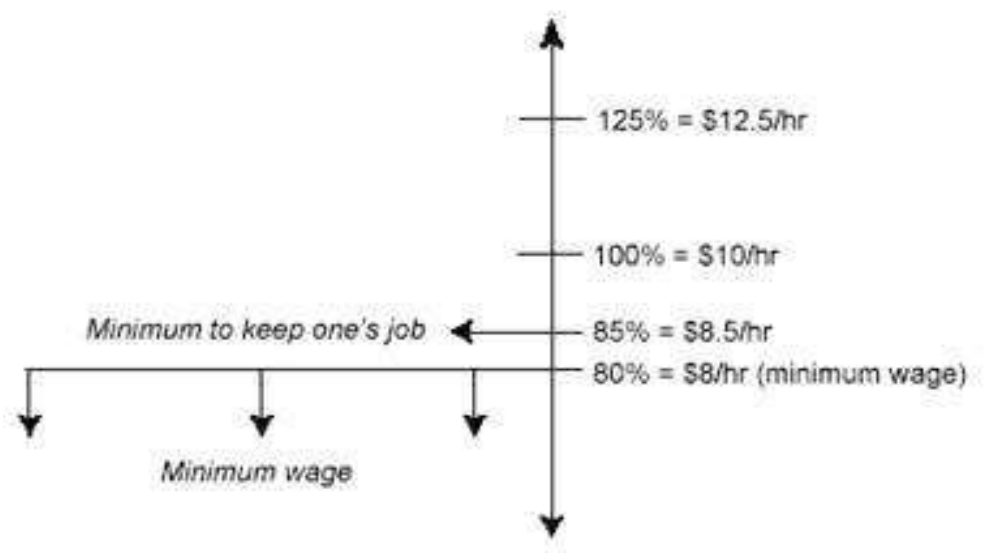

For each person, "making their production" means something different. For some, the goal is to reach $85 \%-100 \%$, which is already hard to do, while others have much higher personal goals. In our sample, 7 of the 9 people for whom we have this information regularly produced more than $100 \%$. "Making your production" can cause tremendous stress. The stress comes in part from the worker's monetary needs, and in part from pressure from supervisors, who are in turn under pressure from company managers what could be called vertical pressure:

She [the supervisor] always wanted $100 \%$, but not in a good way. For example, she would call me, "Do this! Why are you standing up? Why aren't you working? You have to do that! Oh! Yes! Quick! Right away!" Because you know that each supervisor is in charge of one section, so she's concerned about production, and that's how the pressure come. Ruth

Assembly-line work means that workers may also be under pressure from co-workers what could be called horizontal pressure:

For me, if I do a bit less it wouldn't bother me, but the guy who picks up is paid less [but still piecework], and he needs his pay, he wants to do as much as possible because he's paid less. So if I slow down, I slow him down and he won't be pleased with me. You know, if I were all alone, well... but I don't have any choice! So you're always going flat out, as fast as you can. Carl

Assembly-line work also means that workers who aren't on piecework may still be under pressure, a situation that was also noted by Herzog (1980). At Confection Inc., Sid explained:

I work by hour, but I like to give good production...Because after my check someone waiting, like a presser [paid by the piece]. They are waiting so I have to go fast...If I don't go fast they are waiting, they have no work so it's no good.

The demands of production may also result in physical stress. Sewing, for example, imposes stereotyped movements, repeated many times per minute, in a physical environment that cannot be adjusted to the worker's size or shape (Vézina et al. 1992). For one group of pieceworkers, the total weight manipulated with the upper limbs was calculated at $3,486 \mathrm{~kg}$ a day per worker; the pressure of the lower limbs on the pedal at 
16,821 kg (Vézina and Courville 1992). At Confection Inc., Léa was one of many workers who described the physical impact of highly repetitive and very fast work:

I have, it's like cysts, here, because I work my right foot on the pedal, always on the pedal, fast, fast, fast!!

The movements associated with measuring production may also put excessive demands on the body. For example, a C.L.P. decision quoted a medical witness as saying: "It is also essential to note that each bundle of pants picked up means that the worker introduces a smart card into a machine located to her left, above the overlock. The worker therefore again has to perform the abduction movement and internal rotation of the right shoulder.... [This abduction] is repeated as many times as the worker picks up a bundle of pants.... This would seem to be an exhaustive indicator of the repetition of abduction movements performed..$^{13}$

Production demands and the vertical and horizontal pressure of piecework and assemblyline work mean that workers have little control over the pace of their work. The decisions analysed that uphold compensation claims often mention piecework, as this form of remuneration is associated with an accelerated pace or frequent movements. ${ }^{14}$ At the C.L.P., however, employers sometimes argue that there is no set pace of work for pieceworkers, because there is no obligation to produce so much. ${ }^{15}$ In the three cases cited, the C.L.P. did not accept this argument. But in another decision, the Commission did refuse a piecework sewing-machine operator's claim because it considered that the worker controlled the pace of her work: "It is true that Ms. Doan does piecework and that her employer imposes a certain productivity; nevertheless, she still has control over the pace of her work and performs a variety of movements...." ${ }^{16}$

Furthermore, employers at times argue that working by the hour rather than by the piece means that the employee can perform other duties (even if there are production requirements), ${ }^{17}$ or that there is less danger of succumbing to an occupational disease. An excerpt from a decision helps understand the nature of this kind of argument, applied to the situation of a worker who makes the same movement more than 800 times a day: “The employer's representative submitted that Mr. Daraîche's claim did not reveal any particular hazard, the overtime is not significant, the manipulation of the pants was not different than with other pants, the worker is paid by the hour, not the piece, no pace is imposed, his productivity is average, he is not straining in his movements, all the shoulder movements are of limited range. The fact that the worker must from time to time get the pants or move hangers himself only happens occasionally. For these reasons, the employer argues that the worker has not shown that he suffers from an occupational disease." ${ }^{18}$ In these two cases, the tribunal did not accept the employer's arguments. In another case, however, in which the C.L.P. decided that an hourly-paid employee had not suffered an employment injury, the fact that the employee's pace of work was not imposed and that she had sufficient time to recover was considered to be a factor weighing against recognition of the injury. ${ }^{19}$ Our study shows that, on the contrary, hourly-paid employees may also feel pressure to increase their production because of various factors related to the organization of work.

It is also important to mention that in the framework of disputes submitted to the C.L.P., the productivity of employees paid on a piecework basis is regularly used to describe the pace of work. Employers use these data to show that the work is not repetitive, or is less repetitive than for others or than the employee claims. ${ }^{20}$ In these cases, the tribunal has at times sided with the employee, and at times with the employer. 
36 At Confection Inc., there are quality standards as well as production requirements. In fact, the majority of company departments are overseen by both a quantity supervisor and a quality supervisor. Quality requirements may also cause stress, especially when workers perceive them as being contradictory with production requirements - a situation also described by Klein (1964). At Confection Inc., Marie-Ève explained:

It creates a lot of pressure, because, for example, when you work you always have to see what you're doing. If you work just for quantity, not quality, then afterwards... you'll be called into the office.

While production requirements and quality standards may aggravate the stress experienced by workers, meeting one's quota can lead to a very fulfilling sense of personal accomplishment. Roy has also cited the non-economic benefits of piecework, writing: "The element of uncertainty of outcome provided by ever-present possibilities of bad luck made quota attainment an exciting game played against the clock on the wall, a game in which the elements of control provided by the application of knowledge, ingenuity, and speed, heightened interest and led to exhilarating feelings of accomplishment" (Roy, 1953, p. 511). Similarly, at Confection Inc., a number of people, including Karima, talked proudly about their productivity:

My foreman give me nickname "horse"...because I work like that, fast. He say wherever Karima go, she eats everything...I clear out. "Ok, this section, I have too much work, ok if I put Karima here, Karima will clear out everything." So they have a fast worker.

Quotas are fixed, but there are a number of factors that modify working conditions and influence workers' ability to meet their quotas. These production constraints are discussed in the following section.

\subsection{Production constraints}

"The piece-number remains the same from the first day that you slave at it. In the summer your fingers may swell with the heat so that the fitting, welding and punching slow down, but that will not alter the piece-number. If you have a period and so are not able to work so fast, or if your children are ill, then that's your problem! Each woman must trash out of her machine the required piece-number over and over again, every day." (Herzog 1980, p. 102)

Like Herzog and her colleagues, workers at Confection Inc. have to maintain their production in a context of working conditions that vary from day to day, hour to hour and even minute to minute. These individual, material and organizational constraints leave workers in a constant state of insecurity. At the individual level, a worker's physical or psychological condition is mentioned as an important factor:

She produced her $100 \%$, but now that she's pregnant... that's why she's a bit slow, she doesn't want to push herself too much. [She does] between 85 and 90 . Interpreter, talking about Judi

At the material level, workers mentioned various factors that can influence their productivity and therefore their stress level. For instance, they noted that the way the equipment is operating can have a major impact:

If morning [there is a need for] repair, evening time repairman coming. If he is

busy, maybe next day...On that day we can't make production. Malti

The company claims that it adjusts the employee's pay when such things occur. However, some workers have observed problems with adjustments in pay and say that the 
adjustments aren't done systematically. New equipment or new ways of doing things may also influence production:

One technician work here...One day, he came my place. Normally [the pressing machine takes] fourteen seconds to complete. After they put one program, twenty second...I ask, “This take a more time. I can't make a piecework money at twenty second". This guy say, "Oh, shut up, you work". Ahmad

Bundles of garments are also a major material constraint. According to the workers, there are good and bad bundles, the good bundles being the ones that can be processed faster or more easily. Generally speaking, a good bundle is big, contains small sizes, light fabric, identical colours, easier patterns and specific colours (e.g., less unpleasant dyes, colours that make it easier to see threads, etc.). Bad bundles are bad for production, but also for employees' physical and psychological health:

When I really do heavy materials and have to put pressure then there's a little bit [of pain]...because this hand, you press. I use the iron and I have to put more steam, I need to put a little bit more pressure. Delia

Orders are another source of variations. Marie-Ève explained how she reacted to her supervisor's request for a change in colour to accommodate production needs:

I had a big lot in the same colour and then he [the supervisor] wanted me to do the rush jobs [urgent orders]. I have to change colours to do the rushes. I didn't really want to change the thread to do the rush!... Especially when we're beginning the work and don't really see the quantity we'll be doing.... And then I shouted, I said, "No, I don't want to!" But I shouted, I cried, I was really angry... When they ask for that, it's demanding!

Orders also cause a lack of regularity in the quantity of materials available. The company's policy is that before an employee can be paid by the hour, they have to have been without work for a minimum of 20 minutes, which is an eternity for pieceworkers. As well, workers have to ask to be put on an hourly rate. Some talked about favouritism or lack of concern on the part of supervisors, who wait unnecessarily before putting them on an hourly rate.

The lack of regularity in the quality and quantity of materials stems also from the behaviour of auxiliary workers, who move the bundles of garments to be made up from one operation to the next and distribute them to the workers. A number of people talked about favouritism practised by these workers, a situation also observed by Klein (1964). At Confection Inc., Ruth explained:

Sometimes it comes in large, large, large, after that comes medium, after that small, and all the large goes only to one person.

According to the workers, auxiliary workers give the good bundles to the faster workers, the ones they prefer for reasons of friendship, physical appearance or ethnic origins, or in exchange for favours:

When there's a hard job, it has to be shared for the 3 or 4 girls who do the same thing. But sometimes... you go in the next day and you find all the hard stuff beside your machine. What's not hard is beside the others. [When asked if there is favouritism based on ethnicity]: Yes, yes! There's a lot of that. Yes, there's a lot, but I'm never lucky! There aren't many [people from my country]. Léa

There's a woman.... I give her.... good materials to her.... Because sometimes for example... I need money, like $\$ 5$ or $\$ 2$, I ask her and she gives it to me like that... So I favour her. It's a secret between me and her. Ghassan (auxiliary worker) risks. To counter favouritism in the distribution of bundles, workers say they have to be 
constantly on the alert and track what is happening around them, which can contribute to their stress. They also complain regularly to the supervisor, but the latter doesn't always remedy the situation. The company also has a policy of rotating auxiliary workers, but it isn't systematic and isn't necessarily practical, because each auxiliary worker knows the capacities and preferences of the workers in his or her section.

The availability of materials also depends on the auxiliary workers. Alex, an auxiliary worker, explained that it is hard for him to go to the washroom, because the people who depend on him will lack work:

It happened to me once (laughs). I needed to go to the washroom so badly. There was one man with just 5 bundles. That's about... 25 pieces, 10 minutes to finish them. So I said, "I'll go." But after that I came back, and the man said, "Oh, where were you? Look, I don't have anything more to cut." I said, "Sorry, sir, I had to go to the washroom."

A number of people also mentioned that some auxiliary workers, paid by the hour, work slowly, and this can be stressful for the people who depend on their work:

Before, there was a [person of a certain origin], a little guy, who worked here... he was the one who distributed the work. But he didn't work! At first it was OK, and then afterwards he didn't like the work, it didn't pay well and it was tiring... He was always gone off to the washroom or somewhere else, we didn't know where he was, eh, and when that happened we scolded him a bit... We didn't have anything to do. Meili

A similar situation has been noted by Burawoy (1980), who wrote "For operators paid by the piece, time lost was money lost; for auxiliary workers paid by the hour, time lost was effort saved." (p.273)

Given these factors, it is hardly surprising that auxiliary workers report being subjected to psychological and physical violence regularly:

The man was really angry. He said to me, "If you give me bundles of 3, I'm going to come out and hit you." I said, "But why would you do that? It's my job to give you the work, and you have to get it done... I gave him the work. After that he was angry. When I turned back... he gave me a blow here, in the back, a punch (laughs)... And for that I spoke to the boss. He came here, and the man was suspended. Alex

In addition to a lack of regularity in the quality and quantity of materials, workers are also faced with constraints related to changes in duties. The majority of employees, especially the new ones, are assigned more than one task at work in the hope of preventing health problems related to repetitive movements. ${ }^{21}$ For some tasks, there are also variations with different quotas. Changes in duties require time to readjust, and that slows down production. As well, some duties or variations on duties are harder than others, and this can cause workers a great deal of anguish.

We're always being switched around!...They say, "Here there's a lot of work, there, there isn't" and then I go to where there's a lot of work to help or not. But for me it's not good... when you arrive in a place you do things differently, you understand? ...I was very nervous... I couldn't do my $100 \% . .$. because there are places where it's easier and places where it's not. Lourdes (when she was on piecework)

Changes in rates of pay are another source of pressure. When the production of the majority of workers on a task is high, the quotas for that work are increased. Many authors have described collective forms of control of production, aimed at regulating rates (Edwards and Scullion 1982; Levine 1992; Roy 1952). The result is that some people 
feel anxious about other people's production, or by the way others view their production. Lourdes, for example, explained:

They were always looking at me: "Hey, why do you do so much? After... they pile it on!" I've always worked, so what am I going to do, wait here and dawdle? She scolded me because I did a lot.... And then one day I got angry and told my boss, and I said, "Excuse me, why does she come here and stare at me..." I always said that she was out to quarrel with me about how much I do.

The increase in rates may also have an effect on workers' physical health, by encouraging them to increase the speed of work. A few C.L.P. decisions mention this situation, with workers reporting a deterioration in their state of health following a demand for increased productivity. ${ }^{22}$ In a number of cases, the tribunal also makes a connection between a demand for greater productivity and an employment injury. ${ }^{23}$

At the time of the interviews, Confection Inc. was giving employees bonuses when production quotas were raised, but the bonuses were not given to employees newly assigned to the task concerned. So for the same task, there may be differences in the number of pieces required to obtain the same pay, and this causes some workers to resent their colleagues:

They asked to have a bonus, y'know, because at first the rates weren't right, supposedly, but they didn't give them to everyone!... And we're all doing the same job.... We cut [clothes], you have to cut 13 an hour to have $100 \%$, but the others, maybe they just have to cut 9 an hour to get $100 \%$... So y'know, I think it's psychological, I think they're playing head games with us! Carl

The company has since changed this practice and is now paying a lump-sum compensatory bonus to employees who worked previously on the operations for which quotas changed like this. Nevertheless, the quota increases constitute a loss of pay for all employees in the long term.

57 Finally, the vagaries of compartmentalized and production line work also give rise to stressful situations, with mistakes made "upstream"' on the assembly line affecting the productive capacity of workers who follow:

I have to check three pieces of material for the same number. Sometime in before section, some people mix the materials...I need 23-23-23. Sometimes, they make 23-25 or 28-29. So at that time we have to untie the bundle and give back. At that time we waste the time. Malti

In short, individual, material and organizational constraints are sources of anxiety for workers, leaving them in a permanent state of insecurity. So workers use various strategies to try and control their working conditions. These strategies are described in the following section.

\subsection{Production strategies}

It's as if we're so afraid we won't get our production done that we're always trying to cheat a bit. Isabelle

Workers at Confection Inc. use various strategies to keep up their production. The use of strategies is explained by the workers' precarious socio-economic status, as well as by the heavy production demands and multiple work constraints. These strategies are not limited to Confection Inc., as can be seen in C.L.P. decisions involving various companies. 
of the strategies used by Confection Inc. workers is of course to increase the pace of their work and, as we have seen, to watch the others and complain to the supervisor. But they have a whole array of strategies. For example, workers sometimes choose to take bundles instead of waiting for them to be distributed by the auxiliary workers, a strategy that is motivated by the lack of regularity in the quantity and quality of the bundles. The practice is forbidden, but it lies at the root of numerous interpersonal conflicts among workers performing the same work:

Sometimes there is no work so if they don't give you by hour...your press will slow down...So sometimes...I go out to take the piece you know. We say the bundle...I take the bundle to me because there is no work...When I get one the guy [a colleague] don't let me get it. He fights me you know. Peter

61 As well as materials, workers squabble over the most productive equipment. Such disputes, caused by a lack of material resources, have been noted elsewhere (Haraszti 1977; Herzog 1980). So at Confection Inc., it is not surprising that a number of people, including Léa, are chagrined by the individualistic and competitive atmosphere that prevails on the floor:

Everybody works for himself. Everybody wants to win all by themselves. When I came in like that, I was kidding around with a girl, he [the supervisor] told me, "Wait a minute, I'll give you some advice: there are no friends here." He was really right... there is no contact ... You know, everybody looks at the small screen there [measuring production], trrrrrrrr...for 1200, 1400 [pieces] and not even contact. If your friend cries, you don't even know what's wrong with her!

In addition to picking out bundles for themselves, a number of people mentioned working through one or both breaks, over the lunch hour or for a while before or after work:

I've done that too [not taking breaks]... For example, it depends on the fabric... like corduroy, for example, it takes time and so yes... I've done it a few times, but not always. Ruth

Working outside regular hours of work affects the total duration of exposure and rest periods. This strategy may also have an effect on co-workers' working conditions, contributing to increases in rates, inequalities in the availability of materials (the good materials being hoarded by the workers who work outside working hours), the refusal on the part of some supervisors to put workers on hourly rates when there's not enough work, and the accumulation of work in the absence of auxiliary workers:

There are 2 men over there, a worker [of a certain nationality] and a [worker with a certain colour of skin]. Oh! Those ones, they never take breaks! Sometimes after a break, when I say, "Oh, everything's blocked here! oh!" I've told my supervisor, "Those ones, they work during the break!" He said, "O.K., O.K., I'll take care of it." He forgot. Ghassan (auxiliary worker)

To counter such practices, supervisors and workers take their breaks at different times. But as the quote from Ghassan illustrates, some supervisors choose to ignore these breaches, especially when demand for production is high. This attitude from supervisors was also noted in Haraszti's study (1977).

Workers also mentioned strategies aimed at not losing time during work. Carl explained that these strategies are necessary because "The purpose of piecework like that is that the machine is never still." For example, a number of people mentioned that they didn't take washroom breaks during work, and talked about the minutes or seconds lost when they did go: 
We don't work by the piece or the hour, we work by the second! Since she has to make 1,300 [pieces] every 8 hours, even the break, she'll calculate the break! Before [the] 9:05 [break], she has to complete...the quantity for the break!...You take 5 minutes to go to the washroom, it's your loss. It's like 20 jackets you have to make up, you have to do it fast, fast, during the break or something. Léa

To avoid having to go to the washroom, some people say that they don't drink water, despite the high temperatures in various parts of the building. As Karima noted, this can have disastrous consequences for people's health:

One of the ladies, friend she told me, she went all the way to the hospital. You know why? She don't go to the toilet. She don't drink the water for 8 hours. I don't know if that's the reason or something but the urine is blocked. My friend asked her "Why don't you drink the water?" She said "Oh if I drink the water I have to go to the washroom. So the time I go to washroom I lose my production".

As well, to avoid losing time or wasting their co-workers' time, workers often wait for breaks or lunch to raise work-related problems with their supervisor or ask for help from their co-workers. This causes a delay in solving problems:

In the worktime everyone rushes, no one can leave their position...Only lunchtime when they...communicate and say something...But you know the event has passed already...You cannot solve the problem right away. Ben

Another strategy that workers use is to ignore safety measures that slow down production:

When we put the cover [needle guard], it's difficult to make piece. So when we speed up...that's why we put the finger inside the machine...The foreman very scared "Oh, what can I do!". They can't take out my finger from the machine. So they call the mechanic. Malti

In addition to ignoring certain safety procedures, workers develop methods of work that help them improve their productivity. Often, though, the method used is not the method they are supposed to use, which may lead to reprimands:
Maybe you know computers...when other components they're running...the processor never stops. Like myself I never stop. So when machine works on this side I can work on other side...And...last week, the management said I work too fast, because I don't follow the instructions. He said "You have to wait for the machine, lift up properly and then close". Ben

Some methods of work used by workers to increase their productivity may have a more direct impact on their health. For instance, a number of people mentioned that they chose to work standing even though they sometimes have the possibility of sitting down:

Some sections...have the chair...At that time they go fast, and so they think to themselves "If I sit maybe production will slow down". Sid

71 To go even faster, workers plan their day of work as much as possible. Carl compares his work as a cutter to a game of chess, the goal being to take the small bundles:

We move the machines beside the tables with the bundles. The other [worker] is going to get the good bundles... Because while [the machine] is cutting, we see them, the tables are right there... Sometimes there's a small bundle on the table there, and then... he'll come over here [where the small bundle is], because behind it there are big bundles, so he won't go over there to leave me the small bundle, he'll block me so that I can't reach over his machine. So if there're two small bundles there, of course he won't do this small bundle here [the one further away] first, he'll go to the small one [that's closer]. He'll put himself here, he'll do this small bundle, he's greedy and then he'll do the other one after! 
Carl's example also illustrates the individualistic and competitive spirit reigning on the floor that we have already described. Some workers, however, also mentioned cooperating with their co-workers to increase their production. For example, workers paid by the piece sometimes pass on bad bundles to workers being paid by the hour:

As I said, with [a person from a certain country], we respect each other...If one day there's no work and there's an off [meaning that Carl is being paid by the hour, while the other person is still on piecework], what I'll do is all the big bundles there... I'll do them, and I'll leave him all the small ones so that he makes money... And he's the same, he'll do the same for me. Carl

At Confection Inc., workers also mentioned that sometimes the hourly-rated employees had the bundles they completed added to the count for co-workers on piecework, a situation that Herzog (1980) also experienced and described. People on piecework also traded bundles by colour to avoid having to change the thread:

I have two girls who help me... Like if there's a bundle... there are 2 beige and 3

blue, do we change the thread? No!... I can do the 2 beige instead of her. Léa

Workers also help each other out with the machines, as Lourdes, who works by the hour, explained:

If there's a problem they ask me all the time, even if it's a problem with the machine... The girl says to me, "How come you're not a mechanic?" Because sometimes I fix the machine and they're happy, because they get more production done.

This kind of collaboration can have a positive impact on workers' psychological health, by providing protective social support and making it easier to keep up production despite work constraints. But as we have seen, most of the production strategies used by workers can also have a detrimental effect on their health. The choice between production and health is not really a choice, when you consider the workers' precarious position and the demands and constraints of the work. In fact, it is wrong to say that the workers are not concerned about their health. We will discuss strategies conducive to better health in the next section.

\subsection{Strategies for protecting one's health}

76 Workers at Confection Inc. have various individual strategies to protect their health, such as the use of equipment (e.g, gloves, cushions) or forms of behaviour (e.g., stretching exercises, methods of work). Some of these strategies are a direct choice of health over production. For instance, a number of people talked about needing to be healthy for their own personal well-being and that of their family. As Shakeel put it:

I don't like to die because behind I have a wife, I have baby, I have to think about my baby's future, for her I have to live.

This consideration for their health means that some people prefer working by the hour instead of on piecework, even if it means that they stay on a flat salary. According to Lourdes, who has done piecework in the past and now works by the hour (on light duties) because of an illness:

When someone works by the piece, they're killing themselves; a person works by the hour and manages.

Furthermore, some people prefer to have more than one job to do: 
The different jobs, it's good for health...I would say it's good. Because some people they cannot continue to sit down. Some people they cannot continue to stand up...So why not...two hours work sit down job, and come back and stand up job. Karima

79 Some people, like Malti, also mentioned that it was important for their health to take their breaks and go to the washroom during working hours:

When [comes] Thursday, Friday, I can't continuously sitting and stitching. Because I feel pain, back pain. So I stand and go washroom, and drink water. Just a little walk.

Another strategy is to limit one's production:

Maybe if I wanted to make $140 \%$, I'd be stressed. Because it must be a lot of stress if you want to make $140 .$. If I make $140 \%$ it'll have a big impact [on my health]...It's a compromise you have to make. Chloé

81 Sometimes, the decision to limit production is made as a result of a health problem, as this quote from Peter illustrates:

Too fast, my shoulder is pain. I think it's no good. So now I slow down. Even if you pay me more money I will not work so fast like before.

Others, like Ruth, mentioned working intensively to meet their target so as to be able to take short breaks afterwards:

When I succeed in doing what I want to do... I practically stop... I take a little break and I go to the washroom... I give myself time to arrange my material... I'll be more comfortable, I'll relax a bit.

The need for human contact at work, despite obstacles related to production requirements, supervisors' disapproval and the noise of the machines, means that some people choose to talk with their co-workers, even if it means a compromise in terms of productivity. Marie-Ève, for example, explained:

I don't give it all I've got. I give $90 \%$, but the other $10 \%$ I keep for myself (laughs). Because I have to raise my head when someone goes by. If the person wants to say hello to me, I have to answer. If the person smiles at me, I smile too. So I really can't give $100 \%$ to the operation. And it's good for your health too, because sometimes we need to raise our head to move a bit.

\subsection{Managing health problems}

Certain organizational factors influence the way that workers experience their health problems. First, workers note certain contradictions in the attitudes of managers who sometimes emphasize production, sometimes safety. Carl explained:

They say: "O.K. there, slow down! You know you're not obliged to go that fast." But they pay us by the piece so that we'll go faster! But when something happens, it's

"Slow down! Y'know, stop the machine!... No, no, no, you're going too fast!"

It's in fact in the company's interest not to report accidents or illnesses, because these drive up the premiums the company pays to the Commission de la santé et de la sécurité du travail (CSST) for workers' compensation. But faced with international competition, companies want to improve productivity above all. Some adopt a strategy of limiting claims by systematically contesting them, for example (Lippel et al. 2005). Various other factors encourage workers with health problems that could be work-related not to submit claims: a lack of information; communications problems; fear of repercussions (reprisals, dismissal); co-workers' negative experiences; lack of enough financial leeway to wait for compensation; uncertainty about the source of the health problem, especially when it 
involves musculoskeletal disorders (Lippel et al. 1999); etc. In fact, our interviews showed that under-reporting of accidents and especially illnesses is widespread. Of the 27 people for whom we have the information, 23 described diagnosed or undiagnosed health problems that they associate with their work (see Table I). Most of these problems had not been reported to the employer.

There is no salary insurance at Confection Inc. People who don't file a claim with the CSST for workers' compensation and who are unable to work wind up on sick leave, receiving unemployment insurance benefits if the problem causes an absence of more than two weeks, which means a loss of money and rights in the event of complications. Those who are able sometimes continue working when they are sick:

My co-worker, for example, has the same problem [work accident], but she says nothing, nothing at all. She puts on a bandage, for example... Her position: her husband is a student, she has to work, so she doesn't say anything at all... She wouldn't want to lose her job because she still has her case, it's with immigration, and she'll never miss work. Ruth

People with a medical opinion assigning them to light duties are sometimes transferred to a section dedicated to light duties, but they are sometimes given the same work, paid by the hour. This is the case for pregnant women, since the C.A.L.P. ${ }^{25}$ ruled on this kind of assignment in 1992 in Canadelle and Durette. ${ }^{26}$ In that case, the worker - a sewing-machine operator on piecework - was reassigned by her employer after she exercised her right to protective leave or reassignment for pregnant workers. The assignment consisted in an authorization to take 10-minute breaks after each hour of work and to get up to go to the washroom or drink water as often as she wanted. The tribunal in this case decided that the assignment eliminated the dangers identified in the medical certificate. This decision meant that the worker stayed on the job for her entire pregnancy, paid on an hourly basis. This practice of assigning hourly-paid work occurs at Confection Inc., and it can be observed that while these people are paid by the hour, the nature of assembly-line work means that there is still pressure nonetheless. The company expects a certain productivity here too, especially when there is extra work because of orders. Even though some employees prefer to work by the hour on the same jobs as before, either so as not to lose their rhythm or out of a sense of responsibility, many deplore this system because it doesn't necessarily eliminate the pressure or the physical workload:

Even by the hour... we still have the same work to do, sometimes my supervisor had really a lot of work. But then just taking the bundles like that and moving them around, the pain came back. Isabelle

Workers who were absent from work for an extended period of time, be it for a workrelated health problem or to give birth, talked about the problems they encountered when they returned to work. The problems were even greater when production quotas had gone up in the meantime. The company allows them a certain period of readjustment without warnings or the threat of dismissal, and informally gives them a week paid by the hour. But the workers still lose pay:

I really quote unquote slogged away to get my pay, because... when I came back I started all over at the bottom of the ladder...I had to really work hard to get the pay I have now. Isabelle

Our reading of C.L.P. decisions shows that employers do often require workers to return to their piecework positions as quickly as possible. For example, in Teresa Visconti and Manufacture Lingerie Le Château Inc., the tribunal reported in these terms its understanding of the testimony given by the human resources manager: "When a worker is temporarily 
unable to work in her piecework position because of a health problem or employment injury, he is transferred to an hourly paid position. This is what the worker had after sending in her claim to the CSST... But after the CSST rejected her claim, he had to require that the worker return to her position. Because she couldn't do so, he put her on sick leave." ${ }^{27}$ Similarly, in Maunise Alaine and Manufacturier de Bas Iris Inc., the decision says: "After two and a half months of light duties, she [the worker] resumed regular work, at first with hourly pay, but she quickly had to go on to piecework, because the employer doesn't tolerate a worker not being able to resume piecework." ${ }^{28}$

The decisions also show that the CSST's rehabilitation service does not always take into account the realities of piecework and assembly-line work. In one case, ${ }^{29}$ a worker who had returned to work following an employment injury argued that her job was not suitable, in particular because she was incapable of achieving the production bonus while following one of the CSST's recommendations - i.e., to take one piece of clothing at a time: "By taking fewer pieces at a time... she was obliged to do more handling. She lost time and the speed with which she worked was reduced. The worker explained that it was assembly-line work... the girl filling boxes was putting pressure on her to go faster, and that made her feel ill at ease." In this case, the tribunal decided that the position was suitable, but that the worker was entitled to a reduced income replacement benefit designed to maintain her income despite her loss of productivity due to the employment injury.

\subsection{Impact of work-related health problems}

Many workers at Confection Inc. mentioned that they had slowed down their production, deliberately or involuntarily, as a result of a work-related health problem. C.L.P. decisions also show that in many cases, workers connect pain caused by work with lower productivity. ${ }^{30}$ However, a health problem does not always mean lower productivity, because as we have seen, workers work when they are sick or use different strategies to maintain their production. Sometimes, however, this is detrimental to them. We have identified a few C.L.P. decisions, dealing in particular with back problems, in which the tribunal refused a compensation claim partly because of the absence of a significant reduction in productivity. ${ }^{31}$

Reduced productivity means reduced pay, and so some people mentioned finding other work to make up for the loss of earnings. For example, Shezam, who suffered back pain that prevented him from earning as much from his work as he had before, found extra work as a cook to compensate for the reduction in pay:

The restaurant job...part-time job, three hours, four hours...I need money, my

salary is going down...because of the production, so I have to balance.

The result is a paradoxical situation in which a worker is forced to take another job because of a potentially chronic health problem, something that does not help improve his condition. Furthermore, a worker who works for different employers isn't paid for overtime, whereas overtime work would be paid at a higher rate if all the hours were worked for the same employer. It should be noted that a health problem may also affect a worker's ability to keep an extra job.

Health problems resulting from work may affect workers' occupational mobility as well, a situation also described by Patry et al. (2005). For instance, a number of workers reported that their health problems made it harder for them to get a job: 
If I go to the outside to find a job, it's more difficult for me because I'm sick. I have a problem but I know the problem is here so that's why I work here. Ann (trained as a physician) lead to increases in workloads. In fact, high demand and low control at work have been associated with physical and psychological problems in various workplaces (Escriba-Aguir 
et al. 2006; Theorell and Karasek 1996). Our study highlights the role of the organization of work rather than individual or cultural differences in the creation of interpersonal conflict. Comparable dynamics, caused by organizational factors such as the lack of auxiliary staff, were also described by Burawoy (1979) in the following terms: "The...dependence with respect to auxiliary personnel has the consequence of redistributing conflict from a hierarchical direction into a lateral direction, in which individual laborers face one another in conflict or competition. " Our results also show that the organization of work contributes to the feelings of injustice experienced by workers, either individually (e.g., by allowing for favouritism on the part of supervisors and auxiliary workers in working conditions) or organizationally (e.g., by setting different production requirements for the same job). Workers' perception of this kind of injustice is found in the literature on organizational justice (Greenberg and Cropanzano 2001), and has been related to health problems at work (Ferrie et al. 2006; Kivimaki et al. 2003).

101 Workers adopt various strategies to keep up their production despite limiting factors. Haraszti (1977) also observed that workers at the tractor plant had to make use of strategies to make their quotas because the quotas weren't calculated on the basis of the time needed for checks and to arrange the material, and didn't taken into consideration the limiting factors. To earn decent pay, workers had to break rules, including safety rules - a way of getting around standards known as "looting" in that setting. In a way, using strategies gives workers control over their working conditions. However, the strategies are a limiting factor themselves, because they often favour production at the expense of health. According to Wrench and Lee (1982), the immediate benefits of a high level of production for pieceworkers are a certainty that can be calculated, while an accident is only considered a possibility (p.522). At Confection Inc., these strategies cause interpersonal conflict, lengthen exposure, shorten breaks, lead to abandoning safety measures, etc. In the context of a study on a brick factory, Trevelyan and Haslam (2001) also pointed out that workers on piecework worked faster and during breaks, which contributed to the musculoskeletal disorders observed, according to the authors.

It is important, however, to note that workers are concerned about their health and do put health before production when it is possible and/or necessary. Some of the health protection strategies we have described have been observed elsewhere. In particular, Linhart (1978) wrote that the workers he observed on the assembly line sometimes managed to get a few minutes ahead in their work so as to smoke a cigarette - "la minute volée" (a stolen moment), as he termed it. Similarly, Teiger (1995) has described how the young French women factory workers she observed worked intensively so as to gain a few seconds to talk with their co-workers. In a context of compartmentalized work, piecework or assembly-line work, where workers are basically isolated, with each worker becoming an extension of her or his machine (Burawoy 1980), human contact becomes especially important. Thus, Teiger's workers, like the workers at Confection Inc., considered that talking to their co-workers, even very briefly, was crucial to their psychological health, despite the fact that the possibilities for conversation were limited by the noise and the organization of work. The impossibility of interacting with co-workers is a source of frustration, as Herzog (1980) noted: she described her profound need for human contact at work and her frustration with aspects that prevented interaction, in particular production requirements and the way work stations were positioned. 
The impact of piecework on health is therefore both physical and psychological, and it may be immediate or more long term - in the case of musculoskeletal disorders, for example. And the health problems in turn have repercussions well beyond the worker's physical or psychological well-being. They have economic and social effects, influencing productivity and pay, the need for an extra job or the ability to keep it, the possibility of taking courses, occupational mobility, family and relatives and future possibilities. On the other hand, health problems are not always properly managed, especially with respect to light duties, rehabilitation and return to work, which do not always take account of the reality of piecework as experienced by workers.

The group can sometimes help prevent health problems related to piecework through support measures and mutual assistance. As we have seen, workers exchange problem bundles or fix co-workers' equipment. But organizational factors limit the possibility for this kind of collaboration that could be beneficial to the workers' health. In particular, inequalities in the quantity and quality of materials and equipment create a climate of competition that gives rise to many interpersonal conflicts and reduces possibilities for collaboration. Piecework and assembly-line work also mean that workers put pressure on each other, because they can't tolerate poor productivity on the part of co-workers on whom they depend to get their bundles. Corporate policy designed to separate ethnic groups on the production floor may also prevent collaboration, which in the workplace often occurs on the basis of ethnicity (Seifert and Messing 2006). At Confection Inc., these mechanisms are present but are limited to time outside the hours of work (breaks, lunch, before or after work) (see Premji et al. 2008 for a detailed explanation).

Our results show as well that the company transfers many of its costs and risks to individual workers. We have seen, for example, that workers bear the loss of productivity associated with work-related accidents and diseases, changes in duties, slowdowns in orders (and delays in being paid by the hour) and health hazards caused by production strategies used to meet requirements despite limiting factors. What is more, the company reprimands workers who use these strategies instead of redefining the aspects of work organization that encourage their use. In 2003, one of the recommendations made in a company-requested audit report on the management of health and safety was the establishment of a log of problems encountered for each type of garment so that the work could be adjusted accordingly. The report also suggested that the company consider putting a ceiling on production bonuses. In 2007, these recommendations had still not been implemented. As we have seen, the union's capacity to introduce changes is limited. It lives with the constant threat of closures and layoffs. It has limited financial resources, because union dues are based on employees' earnings, which are very low. Its priority is therefore to integrate people from different ethnic groups in the workplace and to resolve immediate problems.

\subsection{Legal implications}

Since the decrees were abolished, working conditions in the garment industry in Québec have deteriorated. Moreover, the company does not comply with some of its legal obligations. In particular, employees are paid on the basis of the provincial minimum wage instead of the higher minimum wage legislated for employees in the clothing industry. The company justifies its practice by saying that employees earn a production bonus on top of the general minimum wage. The union has being trying to change this 
situation for years, but without success so far. The work organization also lends itself to non-compliance with labour legislation. Production requirements and constraints encourage employees to use strategies that are bad for their physical or psychological health, such as not going to the washroom and not drinking water, putting off dealing with safety-related problems with the machinery until later, ignoring safety equipment and measures, etc. The organization of work therefore also contributes to noncompliance with the Act respecting occupational health and safety, which explicitly obliges the employer to protect workers' health. As well, heavy production requirements and multiple limiting factors encourage workers to work outside of regular hours of work. The Act respecting labour standards provides for a 30-minute meal break after five consecutive hours of work. But our study shows that many workers work through part or all of their lunch hour. According to the Act, the regular work week for garment workers is 39 hours. But the work week is longer for some of them, because they work outside of the regular hours of work. Thus, in their study on the outsourcing of work in the clothing industry in Australia, Mayhew and Quinlan (1999) wrote: "Since the primary occupational health and safety risk to outworkers arises from a combination of long hours and piecework, such laws [those on labour standards] are arguably more central to preserving their health and well-being than is occupational health and safety legislation" (p.102). Like the Act respecting occupational health and safety, Québec's Act respecting labour standards doesn't really make it possible to take into account the intensification of work associated with various productivity incentives. Apart from Section 51(3) of the Act respecting occupational health and safety, which offers the possibility of challenging an organization of work that adversely affects workers' health (Quinlan 2007), legislative provisions don't regulate the phenomenon of the intensification of work. This situation suggests that as they now stand, these potential protective tools will not adequately protect workers' health.

\subsection{Gender and ethnicity}

Given that the majority of them are women and immigrants, the workers at Confection Inc. experience specific realities, in particular a socio-economic precarity that is not exclusive to them but that takes a distinct form for them. Similar socio-economic realities have been noted among immigrant workers in the clothing industry in Toronto (Gannagé 1999). This precarity, combined with the demands and limitations of work, encourages workers to use strategies that for the most part are detrimental to their health in order to boost their income. As well, the precarity contributes to the feeling of uncertainty associated with the uncertain results of piecework remuneration. The workers' socioeconomic situation also drives them to work overtime, to have one or more extra jobs and to take language or training courses. Men mentioned having additional jobs or taking courses more often than women, a situation partly related to the fact that women are more often responsible for family duties. These various activities accentuate the impact of piecework by both increasing the length of exposure and reducing recovery time. It is therefore important for an examination of occupational health and safety among populations of women and immigrants to incorporate the issues of social and economic integration that lie at the root of these problems.

At Confection Inc., we identified gender differences in the jobs held and the tasks completed within certain job titles. This division of work may affect the nature of the 
risks and work-related health problems encountered by workers. For example, sewingmachine operators, the majority of whom are women, depend on auxiliary workers, who are mostly men. The machine operators don't have much control over their working conditions compared to auxiliary workers, who have a bit more leeway. Indeed, women's work-related health problems and risks have been largely underestimated by decisionmakers, doctors and researchers (Lippel 2003; Messing 1998; Messing and Boutin 1997). Our results show that work that is perceived and defined as light is not free of risk factors.

Ethnicity and gender may also shape health and safety within the same work tasks. In particular, we identified situations where certain supervisors and auxiliary workers showed favouritism in working conditions on the basis of ethnicity and gender that could have an impact on health. Although we did not elaborate on the issue of knowledge of official languages here, this aspect may also affect interpersonal relations that frame working conditions, more specifically relations with supervisors, auxiliary workers and co-workers (Premji et al. 2008). The impact of health problems may differ by ethnicity and gender, inasmuch as health problems affect the occupational mobility of immigrant workers in a specific way (many of them having experienced professional deskilling) and influence the capacity of women in particular to do the family work for which they are primarily responsible. Our results also indicate that ethnicity plays a role in the underreporting of work-related accidents and diseases because of factors such as a lack of information, problems in communication and fear of repercussions. This could lead to greater use of sick leave or more of a tendency to work even when one is ill. It should be noted that under-reporting has been observed elsewhere (Pransky et al. 1999; Rosenman et al. 2000; Shannon and Lowe 2002), including in workplaces where the majority of employees are immigrant women (Scherzer et al. 2005).

110 Our study is part of an emerging literature showing that there are gender and ethnicity differences within job titles and work tasks that can modify exposure to risks, the nature of health problems, the impact of health problems and recourse in the event of a workrelated accident or disease (Dembe 1999; Frumkin et al. 1999; Lipscomb et al. 2006; Messing et al. 2003). The types of mechanisms identified qualitatively in our study can thus explain the results of epidemiological studies showing differences in health at work by gender and/or ethnicity (see, for example, Wang et al. 2007 for a study showing social inequalities in musculoskeletal disorders among sewing-machine operators). Our study also highlights the role of the organization of work in structuring social inequalities in occupational health and safety.

\subsection{Limits of the study}

111 Our study was done in a large unionized company and carried out in collaboration with the labour federation's status of women committee. The majority of immigrants in Québec, and especially of women immigrants, work for smaller, non-unionized companies (Renaud 2001), to which researchers have limited access. Furthermore, the mechanisms linking piecework and health depend largely on the specific organization of work of the company examined. Thus our study may not be entirely representative of prevailing conditions in these workplaces. 


\section{Conclusion}

112 Piecework may seem archaic. In fact, we noted many similarities between our findings and those of studies done decades ago in very different socio-economic and political contexts. However, this form of remuneration is currently favoured in certain sectors as a way of encouraging employees to produce more. As well, some ergonomists have pointed out a trend in other jobs to favour a quantitative assessment of work. Caroly et al. (2005), for example, have pointed out that the French police force assesses police officers in terms of arrest "figures," which has an adverse effect on prevention of health damage among them.

With strong international competition in the garment industry, piecework is likely to persist and production requirements to increase. An examination of the C.L.P.'s case law shows that piecework is sometimes poorly portrayed by employers or misunderstood by the tribunal. In particular, there is a lack of understanding of the pressure put on hourlypaid workers in a context of work broken down into individual operations and linked in an assembly-line process, the degree of control over the pace of piecework, the reality of conditions prevailing during rehabilitation and upon return to work, and the link between health problems and productivity. In this context, it is therefore imperative to understand the reality of piecework as experienced by workers.

We would like to thank Marie-Claire Lefebvre and Ana-Maria Seifert, as well as the anonymous reviewers for their judicious comments that helped improve this article. The research was made possible by grants from the Fonds québécois de la recherche sur la société et la culture (FQRSC), the Ontario Institute of Work and Health, the Institut Santé et Société (AON bursary) and the Canada Research Chair on Occupational Health and Safety Law, University of Ottawa. The research was carried out with the collaboration of the Fédération des travailleurs et travailleuses du Québec, in particular Carole Gingras and the local union concerned. It is part of the l'Invisible qui fait mal programme, which has a team grant from the FQRSC. The opinions expressed are, however, those of the authors.

\section{BIBLIOGRAPHY}

Brisson, C., Vinet, A., Vézina, M., Gingras, S. (1989). Effect of duration of employment in piecework on severe disability among female garment workers. Scand J Work Environ Health, vol. $15, n^{\circ} 5$, p. 329-34.

Burawoy, M. (1979). Manufacturing consent. Changes in the labor process under monopoly capitalism. Chicago: The University of Chicago Press.

Burawoy, M. (1980). The politics of production and the production of politics: a comparative analysis of piecework machine shops in the United States and Hungary. Political Power and Social Theory, vol. 1, p. 261-299. 
Caroly, S., Boussard, V., Loriol, M. (2005). Du rapport entre jeunes et anciens au collectif de travail : Cas des gardiens de la paix. $X^{\text {ème }}$ Journées de sociologie du travail. Rouen.

Cheng, Y.H. (1997). Explaining disablement in modern times: hand-injured workers' accounts of their injuries in Hong Kong. Social Science and Medicine, vol. 45, $n^{\circ}$ 5, p. 739-750.

Dembe, A. (1999). Social inequalities in occupational health and health care for work-related injuries and illnesses. International Journal of Law and Psychiatry, vol. 22, n 5-6, p. 567-579.

Edwards, P.K., Scullion, H. (1982). The social organization of industrial conflict: control and resistance in the workplace. Oxford: Basil Blackwell.

Escriba-Aguir, V., Martin-Baena, D., Perez-Hoyos, S. (2006). Psychosocial work environment and burnout among emergency medical and nursing staff. Int Arch Occup Environ Health, vol. 80, $\mathrm{n}^{\circ} 2$, p. 127-33.

Ferrie, J.E., Head, J., Shipley, M.J., Vahtera, J., Marmot, M.G., Kivimaki, M. (2006). Injustice at work and incidence of psychiatric morbidity: the Whitehall II study. Occup Environ Med, vol. 63, $\mathrm{n}^{\circ}$ 7, p. 443-50.

Frazer, M.B., Norman, R.W., Wells, R.P., Neumann, P.W. (2003). The effects of job rotation on the risk of reporting low back pain. Ergonomics, vol. 46, n 9, p. 904-19.

Frumkin, H., Walker, E.D., Friedman-Jiménez, G. (1999). Minority workers and communities. Occupational Medicine, vol. 14, $\mathrm{n}^{\circ}$ 3, p. 495-517.

Gannagé, C.M. (1999). The health and safety concerns of immigrant women workers in the Toronto sportswear industry. International Journal of Health Services, vol. 29, n 2, p. 409-429.

Geddes, L.A., Heywood, J.S. (2003). Gender and piece rates, commissions, and bonuses. Industrial Relations, vol. 42, $\mathrm{n}^{\circ} 3, \mathrm{p} .419-444$.

Goulet, L., Thériault, G. (1987). Association between spontaneous abortion and ergonomic factors. A literature review of the epidemiologic evidence. Scand J Work Environ Health, vol. 13, p. 399-403. Greenberg, J., Cropanzano, R. (2001). Advances in organizational justice: Stanford University Press. Haraszti, M. (1977). A worker in a worker's state. Harmondsworth, England: Penguin Books.

Herzog, M. (1980). From hand to mouth. Women and piecework. Markham : Penguin Books.

Institut de la statistique du Québec (2001). Enquête sociale et de santé, 1998, $2^{\mathrm{e}}$ édition. Montréal. Kivimaki, M., Elovainio, M., Vahtera, J., Ferrie, J.E. (2003). Organisational justice and health of employees: prospective cohort study. Occup Environ Med, vol. 60, n 1, p. 27-34.

Klein, L. (1964). Operators' attitudes to piecework. New Society, vol. 16, p. 11-13.

Labelle, M., Turcotte, G., Kempeneers, M., Meintel, D. (1987). Histoires d'immigrées. Itinéraires d'ouvrières Colombiennes, Grecques, Haïtiennes et Portuguaises de Montréal. Montréal : Les Éditions du Boréal Express.

Levine, D.I. (1992). Piece rates, output restriction, and conformism. Journal of Economic Psychology, vol. 13, p. 473-489.

Linhart, R. (1978). L'établi. Paris : Les Éditions de Minuit.

Lippel, K. (2003). Compensation for musculoskeletal disorders in Quebec: systemic discrimination against women workers? International Journal of Health Services, vol. 33, n 2, p. 253-281. 
Lippel, K., Lefebvre, M.-C., Schmidt, C., Caron, J. (2005). Traiter la réclamation ou traiter la personne? Les effets du processus sur la santé des personnes victimes de lésions professionnelles. Montréal : Université du Québec à Montréal, Service aux collectivités.

Lippel, K., Messing, K., Stock, S., Vézina, N. (1999). La preuve de la causalité et l'indemnisation des lésions attribuables au travail répétitif : rencontre des sciences de la santé et du droit. Recueil annuel de Windsor d'accès à la justice, vol. 17, p. 35-85.

Lipscomb, H.J., Loomis, D., McDonald, M.A., Argue, R.A., Wing, S. (2006). A conceptual model of work and health disparities in the United States. International Journal of Health Services, vol. $36, \mathrm{n}^{\circ}$ 1, p. 25-50.

London, M., Bhattacharya, A. (1985). The relation between frequency of industrial lifting and fatigue produced. Journal of Human Ergology, vol. 14, p. 3-13.

Mayhew, C., Quinlan, M. (1999). The effects of outsourcing on occupational health and safety: a comparative study of factory-based workers and outworkers in the Australian clothing industry. International Journal of Health Services, vol. 29, $\mathrm{n}^{\circ}$ 1, p. 83-107.

Messing, K. (2000). La santé des travailleuses : La science est-elle aveugle ? Montréal : Les éditions du remue-ménage.

Messing, K., Boutin, S. (1997). La reconnaissance des conditions difficiles dans les emplois des femmes et les instances gouvernementales en santé et sécurité du travail. Relations Industrielles / Industrial Relations, vol. 52, $\mathrm{n}^{\circ}$ 2, p. 333-362.

Messing, K., Punnett, L., Bond, M., Alexanderson, K., Pyle, J., Zahm, S., Wegman, D., Stock, S.R., deGrosbois, S. (2003). Be the fairest of them all: Challenges and recommendations for the treatment of gender in occupational health research. American Journal of Industrial Medicine, vol. 22, no 109, p. 1-13.

Miles, M.B., Huberman, A.M. (1984). Qualitative data analysis. A sourcebook of new methods. Beverly Hills : SAGE Publications.

Morin, F., Brière, J.-Y. (2003). Le droit de l'emploi au Québec, $2^{e}$ édition. Montréal : Wilson et Lafleur. Nadeau, D., Vézina, M., Vinet, A., Brisson, C. (1990). Travail parcellaire et altérations de la santé mentale chez les opératrices de machines à coudre. Archives des maladies professionnelles de médecine du travail et de sécurité sociale, vol. 51, n 7, p. 479-487.

Park, L.S.-H., Pellow, D.N. (2005). Making the invisible visible: Asian American/Pacific Islander workers in Silicon Valley. AAPI Nexus, vol. 3, $\mathrm{n}^{\circ}$ 1, p. 45-66.

Patry, L., Gravel, S., Boucheron, L., Fournier, M., Vissandjée, B., Kane, M., Beauvais, J. (2005). Accès à l'indemnisation des travailleuses et travailleurs immigrant(e)s victimes de lésions musculo-squelettiques d'origine professionnelle. Montréal : Direction de la santé publique.

Pilon, J.-L. (2005). Le sort de l'industrie du vêtement au Québec dans le contexte actuel de la libéralisation des marchés. La Chronique des Amériques, janvier, $\mathrm{n}^{\circ}$ 2, p. 1-8.

Pransky, G., Snyder, T., Dembe, A., Himmelstein, J. (1999). Under-reporting of work-related disorders in the workplace: a case study and review of the literature. Ergonomics, vol. $42, \mathrm{n}^{\circ} 1$, p. 171-82.

Premji, S., Messing, K., Lippel, K. (2008). Broken English, broken bones? Mechanisms linking language proficiency and occupational health in a Montreal garment factory. International Journal of Health Services, vol. 38, $\mathrm{n}^{\circ}$ 1, p. 1-19. 
Punnett, L., Fine, L.J., Keyserling, W.M., Herrin, G.D., Chaffin, D.B. (2000). Shoulder disorders and postural stress in automobile assembly work. Scand J Work Environ Health, vol. 26, $\mathrm{n}^{\circ}$ 4, p. 283-91.

Quinlan, M. (2007). Organisational restructuring/downsizing, OHS regulation and worker health and wellbeing. International Journal of Law and Psychiatry, vol. 30, $\mathrm{n}^{\circ}$ 4-5, p. 385:399.

Renaud, J. (2001). Ils sont maintenant d'ici ! Les dix premières années au Québec des immigrants admis en 1989. Québec : Les Publications du Québec.

Rosenman, K.D., Gardiner, J.C., Wang, J., Biddle, J., Hogan, A., Reilly, M.J., Roberts, K., Welch, E. (2000). Why most workers with occupational repetitive trauma do not file for workers' compensation. J Occup Environ Med, vol. 42, nº 1, p. 25-34.

Roy, D. (1952). Quota restriction and goldbricking in a machine shop. American Journal of Sociology, vol. 57, nº 5, p. 427-442.

Roy, D. (1953). Work satisfaction and social reward in quota achievement. American Sociological Review, vol. 18, $\mathrm{n}^{\circ}$ 5, p. 507-514.

Roy, D. (1954). Efficiency and the fix: informal intergroup relations in a piecework machine shop. American Journal of Sociology, vol. 60, $\mathrm{n}^{\circ}$ 3, p. 255-266.

Roy, D. (2006a). Cooperation and conflict in the factory: some observations and questions regarding conceptualization of intergroup relations within bureaucratic social structures. Qualitative Sociology, vol. 29, $\mathrm{n}^{\circ}$ 1, p. 59-85.

Roy, D. (2006b). Un sociologue à l'usine. Textes essentiels pour la sociologie du travail. Paris : Éditions La Découverte.

Scherzer, T., Rugulies, R., Krause, N. (2005). Work-related pain and injury and barriers to workers' compensation among Las Vegas hotel room cleaners. Am J Public Health, vol. 95, $\mathrm{n}^{\circ} 3$, p. 483-8.

Schibye, B., Skov, T., Ekner, D., Christiansen, J.U., Sjogaard, G. (1995). Musculoskeletal symptoms among sewing machine operators. Scand J Work Environ Health, vol. 21, nº 6, p. 427-34.

Seifert, A.M., Messing, K. (2006). Cleaning up after globalization: an ergonomic analysis of work activity of hotel cleaners. Antipode, vol. 38, n 3, p. 557-578.

Shannon, H., Lowe, G. (2002). How many injured workers do not file claims for workers' compensation benefits? American Journal of Industrial Medicine, vol. 42, p. 467-473.

Silverstein, B.A., Fine, L.J., Armstrong, T.J. (1986). Hand wrist cumulative trauma disorders in industry. Br J Ind Med, vol. 43, n 11, p. 779-84.

Teiger, C. (1973). Tâches répétitives sous contrainte de temps et charge de travail. Paris : Laboratoire de physiologie du travail et d'ergonomie du CNAM.

Teiger, C. (1995). Parler quand même! Les fonctions des activités langagières non fonctionnelles. In Paroles au travail, ed. Boutet, J., Paris : L'Harmattan.

Theorell, T., Karasek, R.A. (1996). Current issues relating to psychosocial job strain and cardiovascular disease research. J Occup Health Psychol, vol. 1, n 1, p. 9-26.

Trevelyan, F.C., Haslam, R.A. (2001). Musculoskeletal disorders in a handmade brick manufacturing plant. International Journal of Industrial Ergonomics, vol. 27, p. 43-55.

Vézina, M., Vinet, A., Brisson, C. (1989). Le vieillissement prématuré associé à la rémunération au rendement dans l'industrie du vêtement. Le travail humain, vol. 52, nº 3, p. 203-212. 
Vézina, N., Courville, J. (1992). Integrating women into non-traditional jobs. Women and Health, vol. $18, n^{\circ} 3$, p. $97-118$.

Vézina, N., Stock, S., Simard, M., St-Jacques, Y., Marchand, A., Bilodeau, P.-P., Boucher, M., Zaabat, S., Campi, A. (2003). Problèmes musculo-squelettiques et organisation modulaire du travail dans une usine de fabrication de bottes. Montréal : Institut de recherche Robert-Sauvé en santé et en sécurité du travail.

Vézina, N., Tierney, D., Messing, K. (1992). When is light work heavy? Components of the physical workload of sewing machine operators working at piecework rates. Appl Ergon, vol. 23, $\mathrm{n}^{\circ} 4$, p. 268-76.

Vinet, A., Vezina, M., Brisson, C., Bernard, P.M. (1989). Piecework, repetitive work and medicine use in the clothing industry. Soc Sci Med, vol. 28, $\mathrm{n}^{\circ}$ 12, p. 1283-8.

Wang, P.C., Rempel, D., Harrison, R., Chan, J., Ritz, B. (2007). Work-organizational and personal factors associated with upper-body musculoskeletal disorders among sewing machine operators. Occup Environ Med, vol. 64, p. 806-813.

Wells, R., Mathiassen, S.E., Medbo, L., Winkel, J. (2007). Time - A key issue for musculoskeletal health and manufacturing. Appl Ergon, vol. 38, p. 733-744.

Wrench, J., Lee, G. (1982). Piecework and industrial accidents: two contemporary case studies. Sociology, vol. 16, $\mathrm{n}^{\circ}$ 4, p. 512-525.

\section{APPENDIXES}

Appendix 1 Characteristics of interviewees and interpreters

\begin{tabular}{|l|l|l|l|l|l|l|l|}
\hline $\begin{array}{l}\text { Pseudonym } \\
\text { (Interpreter =I) }\end{array}$ & Sex & Immigrant & $\begin{array}{l}\text { Interview } \\
\text { language } \\
\text { (Fr/Eng/ } \\
\text { other) }\end{array}$ & $\begin{array}{l}\text { Family } \\
\text { responsibilities } \\
\text { in Canada }\end{array}$ & $\begin{array}{l}\text { Job } \\
\text { category }\end{array}$ & $\begin{array}{l}\text { Piece- } \\
\text { work } \\
\text { problem } \\
\text { described as } \\
\text { related to } \\
\text { work (now } \\
\text { or in the } \\
\text { past) }\end{array}$ \\
\hline Ahmad & M & Y & E & Y & Pressing & Y & $\begin{array}{l}\text { Burn, pain in } \\
\text { lower and } \\
\text { upper limbs } \\
\text { and back }\end{array}$ \\
\hline Alex & M & Y & F & N & Other & N & None \\
\hline Alicia & F & Y & F & Y & Cutting & Y & $\begin{array}{l}\text { Cut, } \\
\text { allergies, } \\
\text { headaches }\end{array}$ \\
\hline Ann & F & Y & E & Y & Other & N & $\begin{array}{l}\text { Pain in arm, } \\
\text { neck }\end{array}$ \\
\hline
\end{tabular}




\begin{tabular}{|c|c|c|c|c|c|c|c|}
\hline Asha & $\mathrm{F}$ & $\mathrm{Y}$ & Other & A & Sewing & $\mathrm{N}$ & $\begin{array}{l}\text { Needle prick, } \\
\text { pain in } \\
\text { fingers }\end{array}$ \\
\hline Ben & M & $\mathrm{Y}$ & E & $Y$ & Pressing & $\mathrm{Y}$ & $\begin{array}{l}\text { Pain in } \\
\text { fingers and } \\
\text { back }\end{array}$ \\
\hline Carl & M & $\mathrm{N}$ & $\mathrm{F}$ & Y & Cutting & Y & $\begin{array}{l}\text { Cuts, other } \\
\text { accidents }\end{array}$ \\
\hline Chloé & $F$ & $\mathrm{~N}$ & F & A & Pressing & $\mathrm{Y}$ & None \\
\hline Delia & $\mathrm{F}$ & $\mathrm{Y}$ & E & Y & Pressing & Y & $\begin{array}{l}\text { Pain in leg, } \\
\text { wrist and } \\
\text { back }\end{array}$ \\
\hline Farida & $F$ & $\mathrm{Y}$ & $E$ & $\mathrm{Y}$ & Other & $\mathrm{N}$ & Accident \\
\hline Ghassan & M & $\mathrm{Y}$ & $\mathrm{F}$ & A & Other & $\mathrm{N}$ & $\begin{array}{l}\text { Pain in } \\
\text { upper limbs }\end{array}$ \\
\hline Isabelle & $\mathrm{F}$ & $\mathrm{N}$ & F & A & Other & $\mathrm{N}$ & $\begin{array}{l}\text { Tendonitis in } \\
\text { thumb, pain } \\
\text { in arm, sinus } \\
\text { problems }\end{array}$ \\
\hline Jean & M & $\mathrm{Y}$ & F & $\mathrm{N}$ & Other & $\mathrm{N}$ & None \\
\hline Jing & $\mathrm{F}$ & $\mathrm{Y}$ & Other & $\mathrm{Y}$ & Sewing & $\mathrm{Y}$ & $\begin{array}{l}\text { Problem } \\
\text { with vision, } \\
\text { shoulder } \\
\text { pain }\end{array}$ \\
\hline Judi & $\mathrm{F}$ & $\mathrm{Y}$ & Other & A & Sewing & $\mathrm{N}$ & $\begin{array}{l}\text { Shoulder } \\
\text { pain }\end{array}$ \\
\hline Karima & $F$ & $\mathrm{Y}$ & $E$ & $\mathrm{Y}$ & Other & $\mathrm{Y}$ & None \\
\hline Léa & $F$ & $\mathrm{Y}$ & $\mathrm{F}$ & Y & Sewing & Y & $\begin{array}{l}\text { Miscarriages, } \\
\text { foot pain, } \\
\text { accident }\end{array}$ \\
\hline Leyla (I) & F & $\mathrm{Y}$ & E & $\mathrm{Y}$ & $n / a$ & $\mathrm{n} / \mathrm{a}$ & $\mathrm{n} / \mathrm{a}$ \\
\hline Lourdes & $\mathrm{F}$ & $\mathrm{Y}$ & $\mathrm{F}$ & Y & Other & $\mathrm{N}$ & $\begin{array}{l}\text { Tendonitis in } \\
\text { arm, } \\
\text { allergies }\end{array}$ \\
\hline Malcolm (I) & $\mathrm{M}$ & $\mid \mathrm{Y}$ & E & $\mathrm{n} / \mathrm{a}$ & $\mathrm{n} / \mathrm{a}$ & $\mathrm{n} / \mathrm{a}$ & $\mathrm{n} / \mathrm{a}$ \\
\hline
\end{tabular}




\begin{tabular}{|c|c|c|c|c|c|c|c|}
\hline Malti (I) & $\mathrm{F}$ & Y & E & $\mathrm{N}$ & Sewing & $\mathrm{Y}$ & $\begin{array}{l}\text { Needle stick, } \\
\text { back and } \\
\text { shoulder } \\
\text { pain }\end{array}$ \\
\hline Marie-Ève & $\mathrm{F}$ & $Y$ & $\mathrm{~F}$ & $\mathrm{Y}$ & Sewing & $\mathrm{Y}$ & $\begin{array}{l}\text { Pain in one } \\
\text { leg }\end{array}$ \\
\hline Meili & $\mathrm{F}$ & Y & $\mathrm{F}$ & $\mathrm{Y}$ & Pressing & $\mathrm{Y}$ & \begin{tabular}{ll}
\multicolumn{2}{l}{ Eczema, pain } \\
in lower \\
limbs
\end{tabular} \\
\hline Peter (I) & M & $Y$ & E & $\mathrm{Y}$ & Pressing & $\mathrm{Y}$ & $\begin{array}{l}\text { Pain in } \\
\text { shoulder and } \\
\text { hand, } \\
\text { respiratory } \\
\text { problems }\end{array}$ \\
\hline Rahul & M & $\mathrm{Y}$ & E & $\mathrm{Y}$ & Other & $\mathrm{Y}$ & $\begin{array}{l}\text { Pain in } \\
\text { upper limbs } \\
\text { and back }\end{array}$ \\
\hline Ruth & $\mathrm{F}$ & $\mathrm{Y}$ & $\mathrm{F}$ & $\mathrm{N}$ & Pressing & $\mathrm{Y}$ & $\begin{array}{l}\text { Pain in } \\
\text { hands, } \\
\text { inflamed } \\
\text { wrist }\end{array}$ \\
\hline Shakeel & $M$ & $\mathrm{Y}$ & E & $Y$ & Other & $\mathrm{N}$ & $\begin{array}{l}\text { Pain in lower } \\
\text { and upper } \\
\text { limbs, } \\
\text { accident } \\
\text { caused by } \\
\text { violence }\end{array}$ \\
\hline Shezam & M & $Y$ & Other & A & Pressing & Y & Back strain \\
\hline Sid & M & $Y$ & E & $\mathrm{Y}$ & Other & $\mathrm{N}$ & $\begin{array}{l}\text { Pain in lower } \\
\text { and upper } \\
\text { limbs }\end{array}$ \\
\hline
\end{tabular}

Y=yes, N=no, n/a: not available. Job category: Other= Job other than cutting, sewing or pressing. Family responsibilities: $\mathrm{A}=$ has a family but the family is entirely composed of adults assumed to be autonomous.

\section{NOTES}

1. The name of the company is fictitious.

2. Estimates provided by the local union.

3. R.S.Q.A-3.001.

4. All the names are pseudonyms. 
5. Act respecting labour standards, R.S.Q.C.N-1.1.

6. Regulation respecting labour standards specific to certain sectors of the clothing industry, R.Q., c. N-1.1, r.3.1 A. www2.publicationsduquebec.gouv.qc.ca/home.php

7. Act respecting occupational health and safety, R.S.Q.c.S-2.1.

8. Section 51 (3).

9. Data for October 2007.

10. $\$ 7.45$ was the minimum wage at the time of the interview. This was the general rate, not the minimum wage for employees in the clothing industry, which was higher $-\$ 8.00$ an hour at the time (R.R.Q., c. N-1.1, r.3.1, section 3). But the company refuses to pay its employees the rate for the clothing industry.

11. At the time of the interviews, overtime was offered regularly. Since then, overtime has tapered off because orders are down.

12. The company also has a "modular" section employing less than $10 \%$ of the work force. In this section, which produces models that sell for more and favours quality rather than quantity, the company has set a minimum production level of $80 \%$ and a maximum of $110 \%$, as well as a group bonus for quality.

13. See Selvaranjini Kandasamy et Vêtements Peerless inc. C.L.P., no. 122010937, October 9, 2004 (Commissioner Kushner).

14. Franca Barba et Bruno Tricots, Caramy Tricots et Corporation de ski Filmar. C.L.P., no. 125047100 , January 5, 2006 (Commissioner Kushner) ; Thérèse Bolduc et Manufacturiers Ste-Clotilde Inc. C.L.P., no. 127110807, December 5, 2005 (Commissioner Jolicoeur); Linda Labrecque et Canadelle Inc. C.L.P., no. 119043933, July 15, 2005 (Commissioner Boudreault) ; Clairemira Jean-Marie et Les SousVêtements U.M. Inc. C.L.P., no. 126528926, June 23, 2005 (Commissioner Morin) ; Tapash Kumar Das et Vêtements Peerless Inc. C.L.P., no. 119129716, March 3, 2005 (Commissioner Lévesque) ; Vêtements Peerless Inc. et Lilian Castaneda. C.L.P., no. 115887275, February 12, 2004 (Commissioner Suicco); See Tricots Main Inc. et Maria Andrade. C.L.P., no. 121676035, November 28, 2003 (Commissioner Ducharme); See Vêtements Peerless Inc. et Mesquita Benvinda Raposo. C.L.P., no. 119411940, September 11, 2002 (Commissioner Nadeau).

15. See Tricots Main Inc. et Maria Andrade. C.L.P., no. 121676035, November 28, 2003 (Commissioner Ducharme); Claudette Cyr et G.A. Boulet Inc. C.L.P., no. 117814681-1, March 21, 2001 (Commissioner Langlois); Marie Indombe Ifoku et Manufacturier de Bas Iris Inc. C.L.P., no. 117019158-1, December 5, 2000 (Commissioner Vaillancourt).

16. Vêtements Peerless Inc. et Thi Diep Doan. C.L.P., no. 115890998, August 24, 2000 (Commissioner Bélanger).

17. Brigitte Drouin et Les Confections de Beauce Inc. C.L.P., no. 126206390, February 28, 2007 (Commissioner Savard).

18. Henri Paul Daraîche et Corporation Laverdure (F), Jolicoeur ltée, Rosting Pant, et Vêtements Golden Brand Canada ltée. C.L.P., no. 126620731, October 12, 2006 (Commissioner Vaillancourt), par. 45: application for review for cause.

19. Sonia Pothier et Ballin Inc. C.L.P., no. 118606540, June 20, 2001 (Commissioner Gauthier).

20. Brigitte Drouin et Les Confections de Beauce Inc. C.L.P., no. 126206390, February 28, 2007 (Commissioner Savard) ; See Selvaranjini Kandasamy et Vêtements Peerless inc. C.L.P., no. 122010937, October 19, 2004 (Commissioner Kushner); Teresa Visconti et Manufacture Lingerie Le Château. C.L.P., no. 115888760, June 19, 2003 (Commissioner Boucher) ; Vêtements Peerless Inc. et Mesquita Benvinda Raposo. C.L.P., no. 119411940, August 11, 2002 (Commissioner Nadeau); Lynda Boissonneault et Confection St-Gérard Inc. C.L.P., no. 115601379, February 2, 2001 (Commissioner Savard) ; Esterina Delpercio et Signature Renaissance Montréal Inc. C.L.P., no. 115451551, September 6, 2000 (Commissioner Desbois).

21. This practice doesn't guarantee a reduction in musculoskeletal disorders, especially when the various tasks solicit the same parts of the body, as is often the case (Frazer et al. 2003). 
22. See Vêtements Peerless Inc. et Mesquita Benvinda Raposo. C.L.P., no. 119411940, September 11, 2002 (Commissioner Nadeau) ; Pea Pervin Khondaker et Manufacture Lingerie Le Château Inc. C.L.P., no. 117022186, August 9, 2001 (Commissioner Bélanger) ; Lura Alcantara et Vêtements Peerless Inc. C.L.P., no. 114233539, September 13, 2000 (Commissioner Robichaud).

23. Kim Ngu Lieu et Vêtements Peerless Inc. C.L.P., no. 116298886, October 18, 2001 (Commissioner Côté) ; Pea Pervin Khondaker et Manufacture Lingerie Le Château Inc. C.L.P., no. 117022186, August 9, 2001 (Commissioner Bélanger) ; Vêtements Peerless Inc. et Lilian Castaneda. C.L.P., no. 115887275, March 22, 2001 (Commissioner Lamarre); Marie Indombe Ifoku et Manufacturier de Bas Iris Inc. C.L.P., no. 117019158-1, December 5, 2000 (Commissioner Vaillancourt).

24. See Sylvie Lachance et Les Confections des Beauces inc. C.L.P., no. 124805953, July 16, 2004 (Commissioner Savard) ; Tricots Main Inc. et Maria Andrade. C.L.P., no. 121676035, November 28, 2003 (Commissioner Ducharme) ; Teresa Visconti et Manufacture Lingerie Le Château. C.L.P., no. 115888760, June 19, 2003 (Commissioner Boucher); Tricots Main Inc. et Shella Clitis. C.L.P., no. 119215572, January 14, 2002 (Commissioner Lemire); Boualom Boungnavong et Vêtements Peerless Inc . C.L.P., no. 115893182, July 6, 2001 (Commissioner Lemire); Christine Takacs et Confection Troy Ltée. C.L.P., no. 118255199, May 29, 2001 (Commissioner Brazeau).

25. Commission d'appel en matière de lésions professionnelles; this tribunal was replaced by the C.L.P. in 1998.

26. C.A.L.P., no. 0431430, June 19, 1992 (Commissioner Roy).

27. Teresa Visconti et Manufacture Lingerie Le Château. C.L.P., no. 115888760, June 19, 2003 (Commissioner Boucher).

28. Maunise Alaine et Manufacturier de Bas Iris Inc., C.L.P. no. 118975747, February 5, 2003 (Commissioner Sauvé).

29. Brigitte Poulin et REMDEL Inc. C.L.P., no. 117731604, July 18, 2003 (Commissioner Cusson).

30. See Selvaranjini Kandasamy et Vêtements Peerless inc. C.L.P., no. 122010937, October 19, 2004 (Commissioner Kushner); Vêtements Peerless Inc. et Lilian Castaneda. C.L.P., no. 115887275, February 12, 2004 (Commissioner Suicco) ; Claudia Elvira Cano Perez et Christina Amérique Inc. et Christina Amérique Inc. et Claudia Elvira Cano Perez. C.L.P., no. 115900847, November 27, 2000 (Commissioner Suicco).

31. Christine Takacs et Confection Troy Ltée. C.L.P., no. 118255199, May 29, 2001 (Commissioner Brazeau); Lura Alcantara et Vêtements Peerless Inc. C.L.P., no. 114233539, September 13, 2000 (Commissioner Robichaud).

\section{ABSTRACTS}

Few qualitative studies have described the mechanisms by which piecework influences health. We present the results of 25 interviews conducted between 2004 and 2006 in a large garment factory in Montreal. We describe the workforce, made up in large part of women and immigrants, the requirements and constraints of production, workers' strategies favouring production and those favouring health, and the management and impact of the health problems experienced by workers. In addition, we compare the experience of piecework to its representation by various stakeholders (employers, workers, decision-makers, doctors) as reported in 62 decisions regarding compensation claims for work-related health problems rendered by the Commission des lésions professionnelles (C.L.P.) between 2000 and 2007, decisions pertaining to the garment 
industry and mentioning piecework. We examine the causes and discuss the implications of our results.

Peu d'études qualitatives ont décrit les mécanismes par lesquels le travail à la pièce influence la santé. Nous présentons les résultats de 25 entrevues réalisées entre 2004 et 2006 dans une grande entreprise de fabrication de vêtements à Montréal. Nous décrivons la main- d'œuvre, constituée en grande majorité de femmes et d'immigrants, les exigences et contraintes de production, les stratégies des travailleurs et travailleuses favorisant la production et celles favorisant la santé, et la gestion et l'impact des problèmes de santé vécus au travail. De plus, nous confrontons la réalité du travail à la pièce à la représentation que s'en font différents intervenants (employeurs, travailleurs, travailleuses décideurs, médecins) telle qu'elle a été rapportée dans 62 décisions sur des réclamations pour lésion professionnelle rendues par la Commission des lésions professionnelles (C.L.P.) entre 2000 et 2007, décisions portant sur l'industrie du vêtement et mentionnant le travail à la pièce. Nous examinons les causes et discutons des implications de nos résultats.

Pocos estudios cualitativos describieron los mecanismos por los cuales el trabajo a destajo influencia la salud. Presentamos los resultados de 25 entrevistas realizadas entre el 2004 y el 2006 en una gran empresa de confección de vestimenta en Montreal. Describimos la mano de obra, constituida en gran parte por mujeres e inmigrantes; las exigencias y las dificultades de la producción ; las estrategias de los trabajadores y de las trabajadoras que favorecen la producción como también aquellas que favorecen la salud; y la gestión y el impacto de los problemas de salud que se viven en el trabajo. Además, confrontamos la realidad del trabajo a destajo con la representación que sobre ella se hacen diferentes personas claves (empleadores, trabajadores, trabajadoras, médicos y personas con poder de decisión). Esta representación se deduce de lo señalado en los reportes de 62 decisiones rendidas por la Comisión de lesiones profesionales (C.L.P.) entre el 2000 y el 2007. Estas decisiones, relacionadas con reclamos por lesiones profesionales, corresponden a casos ocurridos en la industria de la confección, en los que se mencionaba el trabajo a destajo. Examinamos las causas y discutimos las implicancias de los resultados.

\section{INDEX}

Palabras claves: trabajo a destajo, salud y seguridad en el trabajo, etnicidad, inmigrantes, género

Keywords: piecework, occupational health and safety, ethnicity, immigrants, gender

Mots-clés: travail à la pièce, SST, ethnicité, immigrants, genre

\section{AUTHORS}

\section{STEPHANIE PREMJI}

CINBIOSE, Université du Québec à Montréal, CP 8888, Succ. Centre-ville, Montréal (Québec), H3C 3P8, Canada, Stephanie.premji@internet.uqam.ca

\section{KATHERINE LIPPEL}

Chaire de recherche du Canada en droit de la santé et de la sécurité du travail, Université d'Ottawa, 603, King Edward, Ottawa (Ontario), K1N 6N5, Canada, klippel@uottawa.ca 


\section{KAREN MESSING}

CINBIOSE, Université du Québec à Montréal, CP 8888, Succ. Centre-ville, Montréal (Québec), H3C 3P8, Canada, Messing.karen@uqam.ca 